\title{
Determinants of Capital Structure: Evidence from Fuel and Energy Sector of Pakistan
}

\author{
NOOR AHMED MEMON \\ PhD Scholar at University of Sindh Pakistan. \\ Email: noor_memon12@hotmail.com \\ Tel: 03353455799 \\ GHAZALA TUNIO \\ Lecturer at Mehran University. \\ Email: tunio_ghazala@yahoo.co.uk \\ Tel: 03363142393

\section{Dr. GHULAM MURTAZA SHAH} \\ Department of Business Administration, Badin Campus, University of Sindh. \\ Email: ghulam.murtaza@usindh.edu.pk \\ Tel: 03082903050
}

\begin{abstract}
The key motivation behind this study is to determine the capital structure of fuel and energy sector firms listed in Pakistan Stock Exchange. Data of 18 firms of this industry are analyzed during the period of 2006 to 2017.for this cross section fixed effect model of regression has been employed after the Hausman Test to see the impact of four independent variables such as growth, profitability size and tangibility of assets on leverage (dependent variable). Furthermore Descriptive statistics, correlation, unit root test are also used. The result showed that growth has significant positive association with leverage where as profitability; size and tangibility of assets have negative association with leverage. It is revealed in our study that firms of fuel and energy sectors of Pakistan financed 59.5\% of their assets through debt and $40.5 \%$ with equity. Huge growth and low profitability has been observed in this industry during the research tenure.
\end{abstract}

Keywords: Capital Structure, Pecking Order Theory, Fuel and Energy Sector, Pakistan Stock Exchange.

\section{Introduction}

Capital is most important thing for any business. Without enough capital no business can even think to carry its operations. The achievement of any firm depends upon the right selection of capital mix and its use. Managers of the firms have to take numerous crucial decisions in order to enlarge the wealth of stakeholders. Capital financing is one of that decisions which affects the firm's financial position. Normally companies can be financed through retain earnings, equity and debt. Therefore, firms managers has to decide best mixture of capital structure which could satisfy the current and future need of firm along with minimum cost of capital. Obtaining debt or equity has different advantages and disadvantages. Debt financing has advantage over equity financing in the sense of cost, tax reduction maintenance of complete ownership whereas it has disadvantages of paying back principal amount with interest, maintenance of minimum cash requirement of lenders, dwindle credit rating and increase the risk of bankruptcy. In this scenario the question arises what is optimal capital structure? How much percentage firm's capital should be financed through debt or equity? What are the chief determinants of capital structure? Since five decades much effort has been taken throughout the world on this topic but researchers and scholars work are not 
very supportive to give lucid direction on optimal capital structure (Drobetz \& Fix, 2003). This invites others to do further research, particularly in country like Pakistan where limited efforts has been done on this topic.

Debate of capital structure initiated with the effort of (Modigliani \& Miller, 1958). They stated that in perfect market where there are no costs then the value of firm is not depend on its financing decision but depend on its investment decision. Its means that decision of financing whether from equity or debt is irrelevance to firm's value. But subsequent researchers disagree with their views and called it non realistic approach because in real world there are taxes, fees, transactional costs etc. Theory of Modigliani and Miller provide basis for other theories like tradeoff, pecking, agency cost, signaling etc.

\section{Research Objective}

The main objective of this work is to empirically investigate the determinants of the Capital structure of fuel and energy sectors firm listed in the PSX during the time period of 2006 to 2017. This study extend the work of (A. Shah, Hijazi, \& Javed, 2004) and used profitability, growth, size and tangibility as independent variables where as leverage as dependent variable.

In the perception of this work, these research questions are formed;

\section{Research Question}

Q1: Is there any significant connection between leverage and Growth of the organizations?

Q2: Is there any significant connection between Leverage and Size of the organizations?

Q3: Is there any significant connection between Leverage and Profitability of organizations?

Q4: Is there any significant connection between Leverage and Tangibility of assets of organizations?

\section{Literature Review}

On this topic, many theories and empirical work has been done all around the world. In this section theories and empirical evidences would be discussed in detail.

\section{Theories of Capital Structure}

\section{Theory of Irrelevance}

This theory is considered as foundation work on capital structure. The chief inspiration of that theory is that market value of firm is not dependent on firm's capital structure. Low or high debt does not impact on firm's value but operating profit does. (Modigliani \& Miller, 1958) believed that CS is completely irrelevant to firm's value but net operating profit, investment decision and risk involved in it has power to decide true value of firm. They assumed that capital market is perfect and there is no cost of taxes, fees, transactions bankruptcy and the information is uniform to all. These hypotheses are seems as impractical because in the practical world costs exists. There is chance of bankruptcy in the real world even it has been seen gigantic firms became bankrupt and it has also seems that internal management and staff has better approach on firms information as compare to outsiders. To cover this unrealistic approach of MM other theories like Trade off, Pecking, Transactional are given.

\section{Trade-off Theory}

This theory is given by (Myers \& Majluf, 1984). As we know that Firm's capital is financed by debt and equity. Managers of firms have to decide best combination of both financing to maximize firm value. In this regard this theory suggested that managers after analyzing the rewards and drawbacks of issuing debt 
over equity try to find best target ratio. According to such ratio they set their current and future polices of capital structure, with this believe it would maximize the firms value. . The best point of target ratio is one where advantage of issuing debt is almost equal to its cost (Chen, 2010).

\section{Pecking order Theory}

The POT was put forward by (Myers \& Majluf, 1984).They have viewed that when organizations require funds for its investment project they prefer following hierarchy in order to meet such need i.e. Internal funding (retain earning), loans and finally issuing equity. According to this the firms that earns high profit, initially meet its investment requirement from internal funds because of availability. After that if need is not fulfilled by that option then they see for the other option that is borrowing debt from banks and public. Likewise final option to meet such need is issuing equity. As we know that internal management is more aware about firm's decisions then investors. This create problem of asymmetric information. When firms required extra funds it brings some costs. The investor believes that outside funds (debt) are less risky than equity (Mac an Bhaird \& Lucey, 2010). Firms that pursue the pecking order theory rejected to have target debt ratio.

\section{Signaling Theory}

This theory was given by (Ross, 1977). According to this theory, when company issues debt or equity it creates some sort of signals. Market feels good when firms go with debt option because it shows investor confidence on firms and market confidence on business to generate positive cash flows to cover interest and principle. At the same time market feels not good when firms issue equity because it gives signal of low confidence and overvaluation of stock price. (Kabir \& Roosenboom, 2003) proved that when firm issue debt it increases value of stock and vice versa.

\section{Agency cost theory}

Jensen \& Meckling (1976) were founders of this theory. Normally agency problem exist in corporations because of separation of management from ownership. Managers try to take decision in their favor rather than shareholders. This theory emphasis on optimum capital structure by minimizing the agency cost. There are three types of costs related with this i.e. cost related with substitution of assets, cost related with underinvestment and cost connected with free cash flows. Managers of firms have to take balanced decisions which can reduce cost associated with capital and increase firm's value at same time.

\section{Empirical Evidence}

After discussing prominent theories of CS there is need arises to look at empirical evidence that has been done so far around the world to validate the prediction of these theories. It has been seen that outcome of empirical evidences are very much different from industry to industry and country to country due to different reasons. In this regard, hypothesis of some theories are valid at one place where as invalid at others. (Harris \& Raviv, 1991) proved in their research that due to tangibility of assets leverage varies from industry to industry. Manufacturing firms uphold high leverage as contrast to high technological firms. (Hennessy \& Whited, 2005) gave evidences that firms that have high liquidity maintain low level of leverage.(Song, 2005) took research to discover determinants of CS of Swedish organizations. He took data of 6000 firms from 1992 to 2000 . He used both short term and long term debt as proxies of leverage. He found that averagely Swedish firms are highly leveraged.(Hijazi \& Naqvi, 2006) took research on cement sector of Pakistan. Data from 1997 to 2001 has been taken. Result of research showed except the firm's size all other variables i.e. profitability, tangibility, growth found significant. To know the determinants of CS of pharmaceutical firms of Pakistan (Masnoon \& Anwar, 2012) conducted research. They took data from 2008 to 2011. Regression analysis had been used to see the effect of six independent variables on leverage .Results of work implied that growth and tangibility have positive significant 
association while profitability and size have significant negative association with leverage while other two variables were found insignificant. (Ullah \& Shah, 2014) took work on non financial organizations of Pakistan. They took data of 445 firms. The result of research showed that there is positive but insignificant connection of tangibility of assets with leverage. Their result also showed that big organizations owing more loans as compare to smaller in Pakistan. Their work did not support extended work of Pecking order theory in Pakistan. (Acaravci, 2015) took research on same topic in turkey. He took data of 79 manufacturing firms from 1993 to 2010. His empirical results signify that all variables i.e. growth opportunities, size, profitability, tangibility are significant except non debt tax shields. His work revealed that trade off and pecking order theories implicated in turkey. (Nasimi, 2016) took data of 15 IT corporations of US to know the most important determinants of CS. He used six independent and three dependent variables. All determinants of study found significant. The study found that IT firms of US prefer debt in CS. (Akhtar, Husnain, \& Mukhtar, 2012) took research on textile (Spinning) organization of Pakistan. Result of his work showed that spinning firms of Pakistan are small in size and they prefer internal financing as compare to external. (M'ng, Rahman, \& Sannacy, 2017) took data of public listed firms of Malaysia, Singapore and Thailand. They took micro as well as macro variables. Their findings support trade off and pecking order theories. Their results showed that profitability and firm size has significant impact on leverage in Singapore and Malaysia whereas insignificant in Thailand. Tangibility of assets has significant positive while depreciation to total assets has significant negative impact in all three countries.

\section{Research Methodology}

Data of 18 organizations related with fuel and energy sector of Pakistan are taken. Sample consist of 12 years beginning from 2006 and ends at 2017. All those organizations are chosen that are continuously enlisted during the research work. The nature of data is secondary that is taken from financial statement analysis of non financial firms listed in PSX by SBP from 2006 to 2017. Therefore, our sample based on 18 cross sections balanced panel for 12 years with 216 observations. In order to see the connection of dependent and independent variable multiple regression analysis was used. After the result of Hausman test fixed effect or random effect model would employed. To analyze the data other tests like descriptive statistics, unit root test, $\mathrm{F}$ test and Pearson correlation would also used.

\section{Model Development}

In order to glimpse at the connection of dependent variable and independent variables regression model is developed. In this model leverage is dependent variable which is regressed against four independent variables such as growth, profitability size and tangibility of assets.

$\mathrm{L}=\mathrm{a} 1+\beta 1 \mathrm{Gj}+\beta 2 \mathrm{Pj}+\beta 2 \mathrm{Sj}+\beta 2 \mathrm{TAj}+\mathrm{ej}$

Where,

$\mathrm{a} 1=$ intercept

$\beta=$ Regression Coefficient

$\mathrm{e}=$ Error Term

$\mathrm{j}=$ firm

$\mathrm{L}=$ Leverage

$\mathrm{G}=$ Growth

$\mathrm{P}=$ Profitability

$\mathrm{S}=$ Size

TA=Tangibility of Assets 


\section{Conceptual Framework}

Based on the literature the study has developed the following literature.

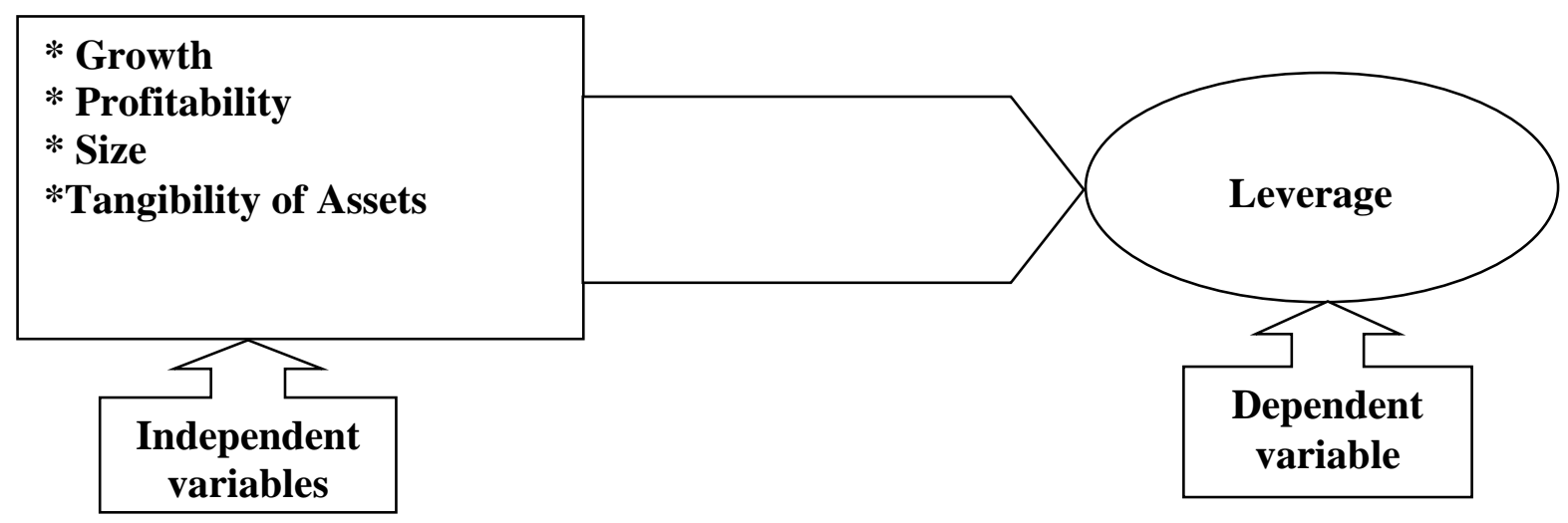

Figure: No1 Study Theoretical model.

\section{Measurement of Variables}

\section{Leverage}

This is our dependent variable of study. This variable is calculated by total debt to total assets.

$\mathrm{L}=\underline{\text { Total debt (current Liabilities+ noncurrent liabilities) }}$

Total assets (current assets+ noncurrent Assets)

\section{Growth}

This is one of the main independent variable of study. It is calculated by change is total assets percentage

$\mathrm{G}=\underline{\text { Total Assets current year minus Total Assets previous year }} * 100$

Total assets previous year

\section{Profitability}

It is also our independent variable that is calculated by dividing net profit before tax to total assets.

$\mathrm{P}=\underline{\text { Net profit before tax }}$

Total assets

\section{Size}

This independent variable is calculated by taking log of current annual sales.

$S=\log ($ current annual sales)

\section{Tangibility of Assets}

This independent variable is calculated by dividing fixed assets to total assets. 


\section{$\mathrm{TA}=\underline{\text { Fixed Assets }}$ \\ Total Assets}

\section{Result and Discussion}

\section{Descriptive Statistics}

The result of table 1 of descriptive statistics showed that value of mean for growth is maximum that is 8.365 while mean value of profitability is minimum that is 0.019 that means that fuel and energy sector of Pakistan has huge growth but the profitability is very low. The growth has also highest deviation which is 22.134 while tangibility of assets has lowest deviation which is 0.173 . The average mean value of leverage is 0.596 with .369 deviation. It confirms that firms of fuel and energy sectors of Pakistan financed 59.5\% of their assets through debt and $40.5 \%$ with equity. Tangibility of assets has mean value of 0.555 with 0.173 deviation. The size has mean value of 6.875 with deviation of 1.264 which is quite high after growth it means that industry assets (growth) and sells (size) are growing dramatically.

Table 1. Descriptive Statistics

\begin{tabular}{|l|c|c|c|c|c|}
\hline & G & L & P & S & T \\
\hline Mean & 8.365 & 0.595 & 0.019 & 6.875 & 0.555 \\
\hline Median & 5.571 & 0.628 & 0.040 & 7.142 & 0.554 \\
\hline Maximum & 98.634 & 1.837 & 0.600 & 8.539 & 0.996 \\
\hline Minimum & -76.139 & 0.014 & -3.174 & 2.300 & 0.095 \\
\hline Std. Dev. & 22.134 & 0.369 & 0.280 & 1.264 & 0.173 \\
\hline Skewness & 0.284 & 0.627 & -7.772 & -1.174 & -0.106 \\
\hline Kurtosis & 6.327 & 3.820 & 85.784 & 4.364 & 2.842 \\
\hline Sum & 1806.823 & 128.482 & 4.160 & 1484.903 & 119.786 \\
\hline Sum Sq. Dev. & 105333.400 & 29.337 & 16.799 & 343.657 & 6.400 \\
\hline
\end{tabular}

\section{Pearson Correlation}

Next step is to check whether problem of multicollinearity exist between the variables or not. For this Pearson correlation test is employed. According to the standard of correlation if correlation of two variables is near to .70 it assumes to be strongest relation between variables and one of the variables must remove in order to avoid problem of multicollinearity. Result of Table no 2 showed that there is no evidence of any strong correlation exists between variables.

Table no 2 Pearson Correlation

\begin{tabular}{|l|c|c|c|c|}
\hline & $\mathbf{G}$ & $\mathbf{P}$ & $\mathbf{S}$ & $\mathbf{T}$ \\
\hline $\mathbf{G}$ & 1.000 & & & \\
\hline $\mathbf{P}$ & 0.347 & 1.000 & & \\
\hline $\mathbf{S}$ & 0.390 & 0.492 & 1.000 & \\
\hline $\mathbf{T}$ & -0.189 & -0.309 & -0.375 & 1.000 \\
\hline
\end{tabular}

\section{Unit Root Test}

Prior to doing the regression analysis, unit root test is employ to check the stationary of the variables. For this, 2 methods i.e. Philips - Prawn Fisher test and Levin, Lin, and Chu test are used. Table 3 and 4 showed the results of above unit roots method. It has been seems that all variables are stationary because both methods results show probability is smaller than 0.05 . In this regard all variables are stationary and can be use for regression analysis. 
Table no 3 Unit Root Test

\begin{tabular}{|l|c|c|c|}
\hline Variables & Method & Statistics & Probability \\
\hline Growth & & -6.2 & 0.00 \\
\hline Leverage & \multirow{4}{*}{$\begin{array}{c}\text { Levin, Lin, and Chu } \\
\text { test }\end{array}$} & -6.5 & 0.00 \\
\cline { 1 - 1 } & & -1.8 & 0.03 \\
\cline { 3 - 4 } Profitability & -3.5 & 0.00 \\
\hline Size & & -1.68 & 0.04 \\
\hline Tangibility of assets & & &
\end{tabular}

Table no 4 Unit Root Test

\begin{tabular}{|l|c|c|c|}
\hline Variables & Method & Statistics & Probability \\
\hline Growth & \multirow{4}{*}{ PP - Fisher } & 147.16 & 0.00 \\
\hline Leverage & 52.94 & 0.00 \\
\cline { 4 - 4 } Profitability & 64.79 & 0.00 \\
\cline { 4 - 4 } Size & 159.66 & $\begin{array}{c}0.00 \\
\left(1^{\text {st }} \text { difference }\right)\end{array}$ \\
\cline { 4 - 4 } & & 55.14 & 0.02 \\
\hline Tangibility of assets & &
\end{tabular}

\section{F-Statistics Test}

To know the impact of independent variables on dependent variable F statistics is used.F Statistics test is used to find out the effect of independent variables on dependent variable. This test provided basis for regression analysis. Result of $\mathrm{F}$ statistics showed in table no 5. The result of F-statistics revealed that the probability of F-statistics is 0.00 that is less than $0.05 \%$ which indicates that our independent variables have jointly impact on our dependent variable.

Table no 5 F-Statistics Test

\begin{tabular}{|c|c|}
\hline F-Statistics & 41.65 \\
\hline Prob (F-statistics) & 0.00 \\
\hline
\end{tabular}

\section{Hausman Test}

Hausman test is used to choose which method is best fit for study. The guideline is that if probability value is more than 0.05 than cross sectional random effect model is fit otherwise cross sectional fixed effect model is best for study. $\mathrm{P}$ value of Hausman test 0.00 that suggest us that cross sectional fixed effect model is fit for our study.

Table no 6 Result of Hausman Test

\begin{tabular}{|c|c|c|c|}
\hline Test Summary & Chi-Sq. Statistic & Chi-Sq. d.f. & Prob. \\
\hline Cross-section random & 14.43 & 4 & 0.00 \\
\hline
\end{tabular}

\section{Multiple Regression analysis of Cross Section Fixed Effect}

Table no 7 showed that result of multiple regression analysis of cross sectional fixed effect model. R square value showed that $81.4 \%$ of the variation in Leverage can be explained through this model. P value of all variables is less than 0.05 , which verified that our all variables are statistically significant. The D-W value is 2.25 that signified that there is no correlation between errors. 


\section{Growth}

The T-value showed growth has positive significant relation with leverage. It shows that when firms have more growth opportunities then they take more debt in their capital structure. This result confirms the prediction of extension Pecking order theory. Extension version of Pecking order theory explains that for growing firms internally generated funds are not enough for that reason they may depend on debt. Our result is also consistent with (Rafiq, 2008), (Hijazi \& Naqvi, 2006) but inconsistent with (Myers, 1977) (Huang, 2006), (Hijazi \& Naqvi, 2006), (Akhtar et al., 2012).

\section{Size}

The T-value of size showed that size has negative relation with leverage with significant $\mathrm{P}$ value. It can be interpreted that raise in size brings -2.037 units decline in debt of firms in fuel and energy sector in Pakistan. Larger firms took less debt as compare to smaller firms in this industry. The result rejects the predictions of trade off theory. Furthermore it is consistent with (Rajan \& Zingales, 1995), (Ahmad, Khan, Ilyas, \& Khan, 2017) results but inconsistent with (Huang, 2006), (Hijazi \& Naqvi, 2006).

\section{Profitability}

The T-value of profitability is -2.844 with statistically significant $\mathrm{P}$ value. It shows that profitability has negative relation with leverage. It means that 1 percent positive change in firm's profitability brings -2.844 negative (decrease) change in firm's leverage. When firms earn profit they have more funds for their asset financing that's why they would not prefer debt and vice versa. Our result supports the prediction of pecking order theory that firms prefer internal financing initially to fulfill their financial needs. This result is consistent with (A. Shah et al., 2004), (Q. Shah, Shah, Raja, \& Naseem, 2012), (Ghani \& Bukhari, 2010), (AHMAD et al., 2017).

\section{Tangibility of Assets}

The T-value of tangibility of assets is -4.839 with statistically significant $\mathrm{P}$ value. It shows that tangibility of assets has strong negative association with leverage. Means the firms which have more fixed assets would not prefer leverage. Tangibility of assets increases leverage decreases and vice versa. Our result rejects trade off theory and support pecking order theory in fuel and energy sector of Pakistan. The result is consistent with (Rajan \& Zingales, 1995), (Huang, 2006) but inconsistent with (A. Shah et al., 2004), (Ghani \& Bukhari, 2010).

Table no 7 -Result of Cross Sectional Fixed Effect Model

\begin{tabular}{|c|c|c|c|c|}
\hline Variable & Coefficient & Std. Error & t-Statistic & Prob. \\
\hline C & 1.305 & 0.253 & 5.161 & 0.000 \\
\hline G & 0.001 & 0.001 & 2.233 & 0.027 \\
\hline S & -0.069 & 0.034 & -2.037 & 0.043 \\
\hline P & -0.158 & 0.056 & -2.844 & 0.005 \\
\hline T & -0.439 & 0.091 & -4.839 & 0.000 \\
\hline Weighted statistics & & \\
\hline \multicolumn{2}{|l}{ R square } & 0.814 \\
\hline \multicolumn{2}{|l}{ Adjusted R Square } & 0.798 \\
\hline Durbin Watson stat & 2.25 \\
\hline
\end{tabular}




\section{Conclusion}

This study was carried out on determinants of capital structure of fuel and energy sector firms listed in Pakistan stock exchange. For this, data of 18 firms of this industry was chosen on the basis of continue listing during the research tenure of 2006 to 2017. Descriptive statistics, correlation unit root test and advanced model of regression i.e. cross section fixed affect model was chosen after the Hausman. Leverage was chosen as dependent variable which was calculated by dividing total debt to total assets. Growth, size, Profitability, Tangibility of assets were chosen as independent variables. The result of descriptive statistics showed that industry has financed $59.5 \%$ assets through debt financing. The result of descriptive also revealed that industry has huge growth in term of assets and sells but profitability is low. The result of cross section fixed effect model revealed that all independent variables are significant. Growth has positive relation with leverage whereas other three variables i.e. size, growth, tangibility has negative relation with leverage. Our result support predictions of simple and extension version of pecking order theory where as reject tradeoff theory.

\section{References}

Acaravci, S. K. (2015). The determinants of capital structure: Evidence from the Turkish manufacturing sector. International Journal of Economics and Financial Issues, 5(1), 158-171.

Ahmad, S., khan, M. N., ilyas, M., \& Khan, M. T. (2017). Capital Structure and its Determinants: A Case of Non-Financial Firms Listed on Pakistan Stock Exchange.

Akhtar, P., Husnain, M., \& Mukhtar, M. A. (2012). The Determinants of Capital Structure: A Case from Pakistan Textile Sector (Spinning Units). Paper presented at the Proceedings of 2nd International Conference on Business Management.

Chen, H. (2010). Macroeconomic conditions and the puzzles of credit spreads and capital structure. The Journal of Finance, 65(6), 2171-2212.

Drobetz, W., \& Fix, R. (2003). What are the determinants of the capital structure? Some evidence for Switzerland. University of Basel. WWZ/Department of Finance, Working Paper, 4(03), 51-75.

Ghani, K., \& Bukhari, S. H. (2010). Determinants of capital structure: a case of listed energy sector companies in Pakistan. Available at SSRN 1860706.

Harris, M., \& Raviv, A. (1991). The theory of capital structure. The Journal of Finance, 46(1), 297-355.

Hennessy, C. A., \& Whited, T. M. (2005). Debt dynamics. The Journal of Finance, 60(3), 1129-1165.

Hijazi, S. T., \& Naqvi, S. (2006). FACTORS AFFECTING STUDENTS'PERFORMANCE. Bangladesh ejournal of Sociology, 3(1).

Huang, G. (2006). The determinants of capital structure: Evidence from China. China economic review, $17(1), 14-36$.

Jensen, M. C., \& Meckling, W. H. (1976). Theory of the firm: Managerial behavior, agency costs and ownership structure. Journal of financial economics, 3(4), 305-360.

Kabir, R., \& Roosenboom, P. (2003). Can the stock market anticipate future operating performance? Evidence from equity rights issues. Journal of Corporate Finance, 9(1), 93-113.

M'ng, J. C. P., Rahman, M., \& Sannacy, S. (2017). The determinants of capital structure: Evidence from public listed companies in Malaysia, Singapore and Thailand. Cogent Economics \& Finance, 5(1), 1418609.

Mac an Bhaird, C., \& Lucey, B. (2010). Determinants of capital structure in Irish SMEs. Small business economics, 35(3), 357-375.

Masnoon, M., \& Anwar, F. (2012). Capital structure Determinants of KSE listed Pharmaceutical companies.

Modigliani, F., \& Miller, M. H. (1958). The cost of capital, corporation finance and the theory of investment. The American, 1,3 .

Myers, S. C. (1977). Determinants of corporate borrowing. Journal of financial economics, 5(2), 147-175.

Myers, S. C., \& Majluf, N. S. (1984). Corporate financing and investment decisions when firms have information that investors do not have. Journal of financial economics, 13(2), 187-221. 
Nasimi, R. N. (2016). Determinants of Capital Structure: An Empirical Evidence from United States. Global Journal of Management and Business Research.

Rafiq, M. (2008). The determinants of capital structure of the chemical industry in Pakistan. The Lahore Journal of Economics, 13(1), 139-158.

Rajan, R. G., \& Zingales, L. (1995). What do we know about capital structure? Some evidence from international data. The Journal of Finance, 50(5), 1421-1460.

Ross, S. A. (1977). The determination of financial structure: the incentive-signalling approach. The bell journal of economics, 23-40.

Shah, A., Hijazi, T., \& Javed, A. Y. (2004). The determinants of capital structure of stock exchange-listed non-financial firms in Pakistan [with comments]. The Pakistan Development Review, 605-618.

Shah, Q., Shah, S., Raja, U., \& Naseem, I. (2012). Determinants of capital structure: empirical analysis of fuel and energy sector of Pakistan. Science Series Data Report, Forthcoming.

Song, H.-S. (2005). Capital structure determinants an empirical study of Swedish companies: KTH Royal Institute of Technology.

Ullah, I., \& Shah, A. (2014). The effect of capital structure on abnormal stock returns: Evidence from Pakistan. Business \& Economic Review, 6(1), 1-18.

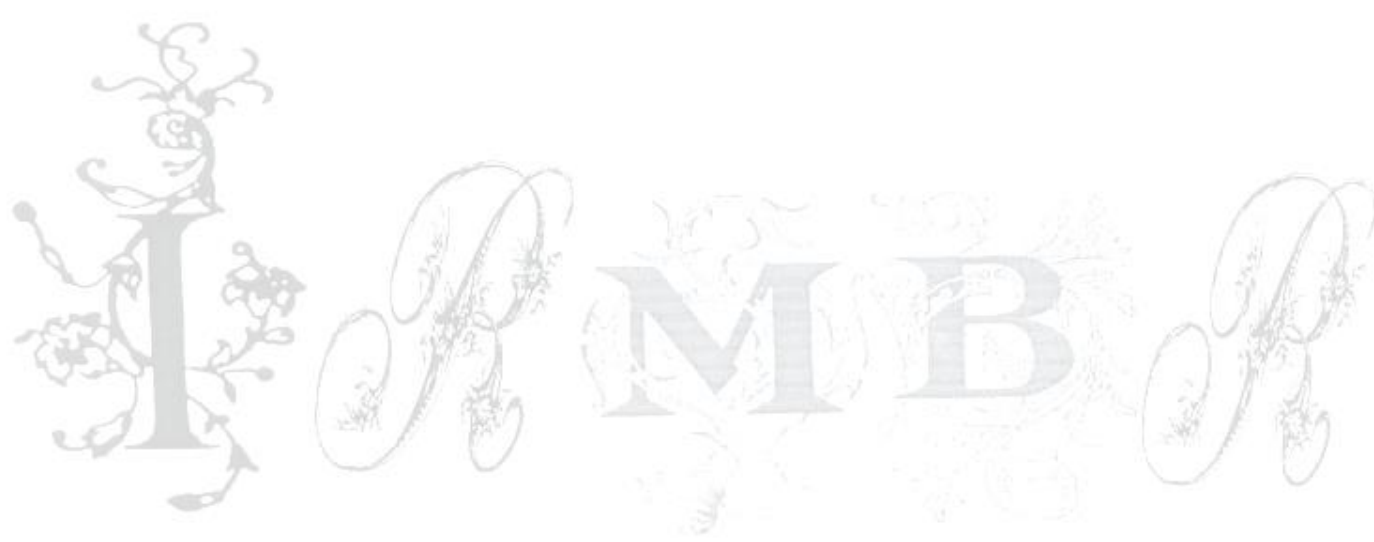

